\title{
Attitudes of Saudi Non-English Major Students Towards Learning English
}

\author{
Nawaf J. Alsubaie \\ Department of English, College of Arts, University of Bisha, Bisha, Saudi Arabia
}

\begin{abstract}
The present study aims at investigating the attitudes of Saudi non-English major students towards learning English at the University of Bisha, Bisha, Saudi Arabia. In addition, the study attempts to identify how the students view the culture of English, English native speakers, and the importance of English in the present time. The data were collected from 80 Saudi non-English major students at the University of Bisha through a three-point Likert scale questionnaire with 13 closed-ended items. The data obtained from the questionnaire were analyzed quantitatively using SPSS. The results of this study show that the students have overall positive attitudes towards learning English. Apart from this, it was found that the students are aware of the importance of English in the present time. Interestingly, the students reflected positive attitudes towards the culture of English and English native speakers. Finally, some implications for teachers and recommendations for future research are presented.
\end{abstract}

Index Terms - attitudes towards EFL, culture of English, Saudi non-English students

\section{INTRODUCTION}

\section{A. Definition of Attitudes}

The first half of the twentieth century witnessed an increasing interest in studying and defining 'attitudes'. In the field of social psychology, an attitude is a complex term that is closely linked with a wide range of other concepts. For example, Mckenzie (2003) identifies 'belief', 'opinion', 'value', 'habit', 'trait', 'motive' and 'ideology', as overlapping concepts with the word 'attitude'. Due to this complexity and interrelation, giving one clear-cut definition of attitudes might be a bit problematic. However, several researchers have already attempted to define the term.

One early definition was suggested by Allport $(1935, \mathrm{p} .810)$ as "a mental or neural state of readiness, organized through experience, exerting a directive or dynamic influence on the individual's response to all objects and situations to which it is related." Allport's definition indicates that an attitude is not inherited but constructed through one's experiences and surroundings. Later definition of attitude was introduced by Ajzan (1988, p.4) as "a disposition to respond favourably or unfavourably to an object, person, institution, or event." This definition regarded attitude as a matter of liking or disliking a particular thing.

Wenden (1991) presents a comprehensive view of attitudes. He classified attitudes into three categories: cognitive, affective and behavioral. The cognitive aspect of attitudes refers to the beliefs and thoughts about an object. The affective one refers to the emotions and feelings about the object, i.e. liking or disliking a particular thing. Finally, the behavioral aspect of attitudes refers to the actions or intentions towards the object.

\section{B. Language Attitudes}

"Attitudes are crucial in language growth or decay, restoration or destruction" (Zeinivand, Azizifar \& Gowhary, 2015, p.241). Language attitudes mean "the extent to which L2 learners perceive the L2, its speakers, its community, its culture as well as the tangible or utilitarian benefits that L2 can bring to its seekers" (Alshami, 2012, p.1). It is an umbrella term that includes a wide range of other concepts. The following classification has been created by Baker (1992), which points to the focuses of language attitudes research over the past years:

- Attitude to language variation, dialect and speech style

- Attitude to learning a new language

- Attitude to a specific minority language (such as Welsh)

- Attitude to language groups, communities, minorities

- Attitude to language lessons

- Attitude of parents to language learning

- Attitude to the uses of a specific language

- Attitude to language preference

The current study falls under the second category of Baker's classification: attitudes to learning a new language.

\section{LITERATURE REVIEW}

\section{A. Role of Attitude in Foreign Language Learning}


Attitude is one of the socio-psychological factors that play a significant role in motivating EFL or ESL learners. It has been extensively studied in the last decades by several researchers. One prominent figure in this field is Robert Gardner, who published several books and research papers attempting to explain this concept and its relationship with second language learning. Gardner and Lambert (1972) introduced a theory which states that to be a successful second language learner, one must be psychologically prepared to accept the practices of the second language's culture and speakers. The learner's attitudes towards the members of the other language determine how successful they are in learning the language.

In his socio-educational model of second language acquisition, Gardner (1985) divided motivation into three aspects: the desire to learn the language, the effort made to learn the language, and the attitudes, or what he calls 'affective reactions' toward learning the language. In this model, Gardner considered attitude as one of the components of motivation. This indicates that the relationship between attitude and second language learning is indirect, unlike motivation, which is obviously a direct relationship.

Ellis (2004, p.320) summarizes language learners' attitudes towards their native culture as well as towards the target culture of the other language in the following table:

TABLE 1.

LEARNERS' ATTITUDES

\begin{tabular}{|l|l|l|}
\hline & Attitudes towards native culture & Attitudes towards target culture \\
\hline Additive bilingualism & + & + \\
Subtractive bilingualism & - & + \\
Semiligualism & - & - \\
Monolingualism & + & - \\
\hline$(+)=$ positive attitudes & $(-)=$ negative attitude
\end{tabular}

As shown in Table (1), monolinguals (those who speak only one language) generally possess negative attitudes towards the target culture, which in return might hinder their learning of the other language.

As mentioned earlier, research on language attitudes, specifically attitudes towards learning English, has been a subject of study in the field of applied linguistics in recent decades. When it comes to the academic context, students' attitudes towards learning English can be affected by factors such as gender, age, field of study, level of education, religion, culture, etc. This, in return, may lead to positive or negative attitudes towards learning the language. In conclusion, based on what has been discussed previously, the following general statement can be given:

Positive attitudes towards L2 $\rightarrow$ High motivation to learn L2 $\rightarrow$ Better performance in L2

\section{B. Review of Related Studies}

In the EFL context, several studies have been conducted to investigate the students' attitudes towards learning English. Adnan (2017) explored the attitudes of 30 Malaysian first-year university students towards English in relation to their native language (Malay) and their religion's language (Arabic). All the participants received their past education in national religious schools. The study found that the students have positive attitudes towards learning English. In addition, they were aware of the importance of English both for their education at the university and their future career while simultaneously valuing Malay and Arabic.

Yosuff (2019) investigated the attitudes of 100 Indonesian non-English major students towards using English in everyday communication. The study showed that the students carry positive attitudes were motivated to communicate in English regularly. Furthermore, they were aware of the importance of learning English in today's world.

Iqbal, Aftab and Azhar (2019) attempted to examine the common assumption that relates the students from Islamic educational backgrounds with negative attitudes towards learning English. The study's sample consists of 151 students from the Islamic Learning Faculty and 135 students from the Education Faculty, both at the University of Karachi, Pakistan. It was revealed that there is only a minor difference in the attitudes of both faculties as the Islamic Learning Faculty's students expressed positivity towards English to a degree lesser than that of Education Faculty's students. Based on the findings of this study, the assumption mentioned above is rejected.

In Afghanistan, Orfan (2020) investigated the cognitive, affective and behavioral attitudes of 210 non-English major students towards learning English in terms of six variables. It was found that the students' overall attitudes were positive. In addition, students' gender, age, first language, and field of study have less impact on their attitudes as compared to the students' access to the Internet and their English learning experience in English language centers.

Some studies discussed the role of age and level of study on students' attitudes towards learning English. For instance, Bhaskar and Soundiraraj (2013) explored the attitudes of 52 Indian first-year Mechanical Engineering students towards learning English. It was revealed that there is a significant shift in the students' attitudes between school and college. At the college level, students' attitudes changed to be more positive.

In Jordan, Abu-Snoubar (2017) measured the impact of gender and field of study on students' attitudes towards learning English at the al-Balqa Applied University. The participants were 176 randomly chosen from the various scientific and humanities faculties at the university. The study found that gender affects students' attitudes as females showed more positivity than males. On the other hand, field of study was found to have no effect on the students' attitudes. 
Al-Tamimi and Shuib (2009) investigated the attitudes of 81 Petroleum Engineering students towards learning English at Hadhramout University of Sciences and Technology, Yemen. The study reported that the students have positive attitudes towards learning English. In addition, the majority of the students showed their interest in the culture of the English-speaking world.

When it comes to Saudi Arabia, several studies, with various focuses, have been conducted to determine college students' attitudes towards learning English. For instance, at Jeddah Community College, Khan (2016) discovered a positive correlation between students' attitudes and their performance in English. Students' proficiency in English was not satisfying even though the educational setting was fully prepared with all the needed equipment and resources for students. The study attributed this issue to students' negative attitudes towards education in general and some other factors such as lack of confidence and fear of making mistakes in English. In this case, the researcher emphasized the teacher's role in improving students' attitudes to learning and encouraging them to use the target language.

Some studies focused on the relationship between students' attitudes towards English and their academic achievement. For example, in a study conducted on 112 English major students at Um Alqura University (Al-Qunfudah branch), Al samadani and Ibnian (2015) found that students with high GPAs expressed positive attitudes towards English more than those with low GPAs.

According to the humble knowledge of the researcher, only one study has been carried out at the same university of the present study (the University of Bisha, Saudi Arabia) and with a similar focus. That is, Ali et al. (2019) investigated the attitudes and perceptions of intensive English program students towards English speaking skills. The participants were from the colleges of Arts, Business and Community. The study revealed that the students' overall attitudes are positive, and students are becoming aware of the importance of English in their future.

After reviewing the literature, it was found that no sufficient studies have touched upon the attitudes of non-English major students towards learning English in the Saudi EFL context, especially at the university of the current study. Therefore, the aim of the present study is to investigate the attitudes of Saudi non-English major students, particularly those majoring in Islamic Studies, Arabic Language and Business Administration, towards learning English at the University of Bisha. Besides, the study attempts to explore the students' attitudes towards the culture of English, its native speakers, and its importance in today's world. Identifying the students' attitudes would help understand the reasons behind the low level of achievement in English courses among Saudi non-English major students in general and at the University of Bisha in particular.

\section{Research Questions}

The present study attempts to answer the following questions:

1. What are the attitudes of Saudi non-English major students at the University of Bisha towards learning English?

2. What are the attitudes of Saudi non-English major students at the University of Bisha towards the culture and native speakers of English?

3. What are the attitudes of Saudi non-English major students at the University of Bisha towards the importance of English in the present time?

\section{METHODOLOGY}

\section{A. Design}

The study follows the quantitative research paradigm. The researcher employs a survey to identify Saudi non-English major students' attitudes towards learning English at the University of Bisha. The researcher chose this paradigm due to its suitability to the present study, which attempts to investigate the attitudes of a large number of students, and so this can easily be done through a questionnaire. In addition, the participants will fill out the questionnaire electronically without any pressure from the researcher.

\section{B. Participants}

The sample of this study consists of 80 Saudi non-English major undergraduate students at the University of Bisha, Saudi Arabia. The classification and demographic information of participants are illustrated below (See Table 2). All the participants have taken an intensive English course at the preparatory year (PY) for 12 hours per week. Besides, before joining the university, they studied English for 7 years, starting from the last stage of primary school until graduating from high school. 
TABLE 2

FREQUENCIES \& PERCENTAGES OF PARTICIPANTS' DEMOGRAPHIC INFORMATION (N=80)

\begin{tabular}{|c|c|c|}
\hline Gender & Frequency & Percentage $(\%)$ \\
Male & 41 & 51.2 \\
Female & 39 & 48.8 \\
\hline Field of Study & Frequency & Percentage $(\%)$ \\
Business Administration & 26 & 32.5 \\
Islamic Studies & 27 & 33.8 \\
Arabic Language & 27 & 33.8 \\
\hline Level of Study & Frequency & Percentage $(\%)$ \\
Second Year & 26 & 32.5 \\
Third Year & 30 & 30 \\
Fourth Year & 24 & 37.5 \\
\hline
\end{tabular}

\section{Instruments}

The study employs a three-point Likert scale questionnaire adapted from Gardener's (1985) attitude and motivation test battery (AMTB) and some related studies. In addition, the questionnaire was slightly modified to suit the Saudi EFL context. The questionnaire carries 13 closed-ended items covering three main aspects (i.e., the three research questions): attitudes towards learning English, attitudes towards the culture and native speakers of English, and attitudes towards the importance of English in the present time (See Appendix A).

\section{Procedures}

After designing the questionnaire, it was translated by the researcher to enable the participants to understand the items clearly, since they are not majored in English. The questionnaire's Arabic translation was revised and approved by a professor of applied linguistics at the University of Bisha. In order to measure the reliability of the questionnaire, Cronbach's Alpha was used. The value of Cronbach's Alpha was (0.724) which is acceptable for this study. After establishing the reliability, the questionnaire was distributed to the target participants electronically through Google Forms. The researcher wrote the instructions and consent form on the cover page of the electronic form of the questionnaire. After reaching the desired number of participants (i.e., 80), the researcher closed the electronic form of the questionnaire.

\section{E. Data Analysis}

The data obtained from the questionnaire were forwarded to Microsoft Excel. The answers were coded as follows: (1) for "disagree", (2) for "neutral", and (3) for "agree". The data were again forwarded to the Statistical Procedure for Social Sciences (SPSS) for the quantitative analysis. The descriptive statistics, including the mean and standard deviation, were used. Means between (1.00 - 1.50) were considered "low", means between $(1.60$ - 2.50) were considered "moderate", and means between (2.60 - 3.00) were considered "high".

\section{RESULTS}

\section{A. The First Research Question}

In order to answer the first research question (i.e., what are the attitudes of Saudi non-English major students at the University of Bisha towards learning English?), descriptive statistics were used. The descriptive statistics included the mean and standard deviation of the students' attitudes towards learning English.

TABLE 3

MEANS \& STANDARD DEVIATIONS OF ATTITUDES TOWARDS LEARNING ENGLISH (N=80)

\begin{tabular}{|l|c|c|c|c|}
\hline \multicolumn{1}{|c|}{ Item } & Min & Max & Mean (M) & Std. Deviation (SD) \\
\hline 1. I enjoy learning English. & 1.00 & 3.00 & 2.41 & 0.81 \\
2. I like communicating only in my mother tongue. & 1.00 & 3.00 & 2.41 & 0.72 \\
3. I have a desire to improve my English level constantly. & 1.00 & 3.00 & 2.65 & 0.62 \\
4. English is a complicated language. & 1.00 & 3.00 & 1.83 & $\mathbf{2 . 3 3}$ \\
\hline \multicolumn{1}{|c|}{ Total } & -- & - & 0.85 & $\mathbf{0 . 2 8}$ \\
\hline
\end{tabular}

Table 3 shows that the mean average of the participants' attitudes towards learning English was (2.33), and the standard deviation was (0.28). This indicates that Saudi non-English major students' attitudes towards learning English are moderate. As shown in Table 3, the item with the highest mean was item 3, "I have a desire to improve my English level constantly."

\section{B. The Second Research Question}

In order to answer the second research question (i.e., what are the attitudes of Saudi non-English major students towards the culture and native speakers of English at the University of Bisha?), descriptive statistics were used. The descriptive statistics included the mean and standard deviation of the students' attitudes towards the culture and native speakers of English. 
TABLE 4

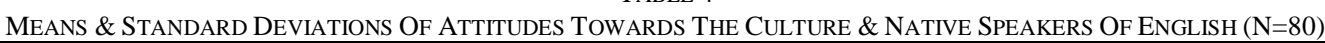

\begin{tabular}{|l|c|c|c|c|}
\hline \multicolumn{1}{|c|}{ Item } & Min & Max & Mean (M) & Std. Deviation (SD) \\
\hline 5. I think it is important to know the culture of any language I want to & 1.00 & 3.00 & 2.65 & \\
learn. & & & \\
6. I like having many friends from English-speaking countries. & 1.00 & 3.00 & 2.50 \\
7. When I learn English, I like to know about its culture. & 1.00 & 3.00 & 2.60 \\
8. Knowing English helps us communicate easily with its speakers. & 1.00 & 3.00 & 2.88 \\
\hline \multicolumn{1}{|c|}{ Total } & -- & -- & 0.71 \\
\hline
\end{tabular}

Table 4 shows that the mean average of the participants' attitudes towards the English culture and native speakers was (2.66), and the standard deviation was (0.42). This points out that the students' attitudes towards the English culture and native speakers are high (i.e., positive). As shown in Table 4, the item that gained the highest mean was item 8 , "Knowing English helps us communicate easily with its speakers."

\section{The Third Research Question}

In order to answer the third research question (i.e., what are the attitudes of Saudi non-English major students at the University of Bisha towards the importance of English in the present time?), descriptive statistics were used. The descriptive statistics included the mean and standard deviation of the students' attitudes towards the importance of English in the present time.

TABLE 5

MeAns \& Standard Deviations Of Attitudes Towards The IMPORTANCE Of EngLish In The Present Time

\begin{tabular}{|l|c|c|c|c|}
\hline \multicolumn{1}{|c|}{ Item } & Min & Max & Mean (M) & Std. Deviation (SD) \\
\hline 9. I think English is important in today's world. & 1.00 & 3.00 & 2.86 \\
10. I think English will play an important role in Saudi Arabia in the & 1.00 & 3.00 & 2.68 \\
future. & & 2.76 \\
$\begin{array}{l}\text { 11. Learning English helps me use the new technologies such as the } \\
\text { internet and databases. }\end{array}$ & 1.00 & 3.00 & 0.59 \\
$\begin{array}{l}\text { 12. Studying English is important because it will make me more } \\
\text { educated. }\end{array}$ & 1.00 & 3.00 & 2.53 \\
13. Learning English is important for my future career. & 1.00 & 3.00 & 2.59 \\
\hline Total & -- & -- & 0.71 \\
\hline
\end{tabular}

Table 5 shows that the mean average of the participants' attitudes towards the importance of English in the present time was (2.68), and the standard deviation was (0.46). This demonstrates that the students' attitudes towards the importance of English in the present time are high (i.e., positive). As shown in Table 5, the item with the highest mean was item 9, "I think English is important in today's world."

\section{DISCUSSION}

The present study is an attempt to investigate the attitudes of Saudi non-English major students towards learning English and its importance in today's world. It also aims at recognizing to what extent the students accept the culture of English and English native speakers. On the contrary to the researcher's expectation, it was found that Saudi nonEnglish major students possess overall positive attitudes towards the English language, learning it, its culture, its native speakers, and its importance in the present time, even though they do not heavily need it during their 4-year study at the university. However, there are some limitations that made it challenging to reach generalizable and detailed results. That is, the study is limited to a sample of 80 non-English major students at a Saudi university (i.e., University of Bisha). In addition, the study is limited to a 3-point Likert scale questionnaire as the main instrument for data collection. The study was carried out in two months during the second semester of the academic year 2020/2021.

The attitudes towards learning English were measured by items 1, 2, 3 and 4. The participants highly desire to improve their current English level constantly $(\mathrm{M}=2.65, \mathrm{SD}=0.62)$. Meanwhile, they were moderately enjoying learning English $(\mathrm{M}=2.41, \mathrm{SD}=0.81)$. The participants were moderately in favor of using only their mother tongue (i.e. Arabic) in communicating and interacting with others $(\mathrm{M}=2.41, \mathrm{SD}=0.72)$. Besides, the participants moderately see English as a complicated language to learn $(\mathrm{M}=1.83, \mathrm{SD}=0.85)$. The results of the previous four items indicate that the participants are aware of the importance of improving their English but simultaneously are neither highly enjoying learning the language nor favoring to use it communicatively, which can be attributed to the traditional and outdated teaching methods practiced by some teachers of English courses.

The attitudes towards the English culture and native speakers were measured by items 5, 6, 7 and 8 . The results of this part were unexpected. The participants think culture is an integral part of the language $(\mathrm{M}=2.65, \mathrm{SD}=0.60)$, so they expressed a liking towards knowing the English culture $(\mathrm{M}=2.60, \mathrm{SD}=0.69)$. Moreover, the participants moderately accept having friends from English-speaking countries $(M=2.50, S D=0.71)$. Meanwhile, the participants think that knowing English is significant to ease the communication with English native speakers $(\mathrm{M}=2.88, \mathrm{SD}=0.37)$. In short, the sample of this study reflected flexibility and open-mindedness towards English culture and native speakers. 
Items 9, 10, 11, 12 and 13 measured the third focus of this study: attitudes towards the importance of English in the present time. The participants showed awareness of the importance of English in today's world $(\mathrm{M}=2.86, \mathrm{SD}=0.38)$. Therefore, they believe in the importance of English in their country's future $(\mathrm{M}=2.68, \mathrm{SD}=0.59)$. The participants moderately think that English will be important in their future careers $(\mathrm{M}=2.59, \mathrm{SD}=0.74)$. The participants also emphasized the importance of knowing English as it helps them use modern technologies such as the Internet and databases $(M=2.76, S D=0.56)$. Finally, the participants moderately correlate knowing English with being an educated and cultured person $(\mathrm{M}=2.53, \mathrm{SD}=0.71)$.

The findings of this study are in agreement with the studies conducted by Yosuff (2019), Orfan (2020), Abu-Snoubar (2017), Iqbal, Aftab and Azhar (2019), and Ali et al. (2019). These studies reported positive attitudes held by the students from non-English majors towards learning English. In addition, the present study supports the studies carried out by Adnan (2017), Bhaskar and Soundiraraj (2013), and Ali et al. (2019). These studies revealed that the students are aware of the significance of English in the present time. Concerning attitudes towards English culture and native speakers, the present study is in line with the study of Al-Tamimi and Shuib (2009), which showed that most of the students have an interest in the culture of the English-speaking world.

\section{CONCLUSION}

The main goal of this study was to investigate the attitudes of Saudi non-English major students at the University of Bisha towards learning English. It was found that the students have overall positive attitudes towards the English language, learning it, its culture, its native speakers, and its importance in the present time. This is a positive indicator placing the responsibility on the shoulders of teachers of English courses. The teachers should constantly keep and enhance the students' attitudes towards learning English, as it is now the first international language. Having positive attitudes towards learning English poses a successful starting point in the students' journey of learning the language. Furthermore, the teachers should improve their teaching methods and use new and creative ones to make students willing to learn the language. Positive attitudes towards learning English accompanied by high-quality teaching methods and a well-designed curriculum would reduce the percentage of failure or low grades in English courses, which is quite common among Saudi non-English major students at the University of Bisha.

The researcher suggests that future research, either at the same university or other Saudi universities, might increase the number of participants, especially for the studies that follow the quantitative research paradigm. That is, a larger sample size would give more generalizable and significant results. Furthermore, future researchers are recommended to use the mixed method research paradigm or qualitative research paradigm, which can lead to more detailed results. Last but not least, further research might figure out the reasons behind the low level of achievement in English courses among Saudi non-English major students despite having positive attitudes towards learning English, as revealed by the current study.

\section{APPENDiX A. ThE QUESTIONNAIRE IN ITS FinAL Form}

\section{Attitudes of Saudi Non-English Major Students towards Learning English}

This questionnaire is part of a research project that investigates the attitudes of Saudi non-English major students towards learning English at the University of Bisha. Your participation will contribute to the achievement of this project which heavily relies on this questionnaire. Your answers will be used for research purposes only and nothing will affect your grades negatively or positively. The questionnaire has 13 short statements that will not take you more than three minutes to complete. The target students in this project are Arabic Language, Business Administration, and Islamic Studies students from level 3 up to level 8.

Thank you in advance for your cooperation.

\section{Gender:}

$\square$ Male

Field of Study:

$\square$ Arabic Language

Level of Study:

$\square$ Second Year
Female

Business Administration $\square$ Islamic Studies

Third Year
Fourth Year 


\begin{tabular}{|c|c|c|c|}
\hline Item & Agree & Neutral & Disagree \\
\hline 1. I enjoy learning English. & & & \\
\hline 2. I like communicating only in my mother tongue. & & & \\
\hline 3. I have a desire to improve my English level constantly. & & & \\
\hline 4. English is a complicated language. & & & \\
\hline 5. I think it is important to know the culture of any language I want to learn. & & & \\
\hline 6. I like having many friends from English-speaking countries. & & & \\
\hline 7. When I learn English, I like to know about its culture. & & & \\
\hline 8. Knowing English helps us communicate easily with its speakers. & & & \\
\hline 9. I think English is important in today's world. & & & \\
\hline 10. I think English will play an important role in Saudi Arabia in the future. & & & \\
\hline 11. Learning English helps me use new technologies such as the internet and databases. & & & \\
\hline 12. Studying English is important because it will make me more educated. & & & \\
\hline 13. Learning English is important for my future career. & & & \\
\hline
\end{tabular}

Appendix B. Frequencies \& Percentages of Attitudes towards Learning English (N=80)

\begin{tabular}{|c|c|c|c|c|c|c|}
\hline \multirow{2}{*}{ Item } & \multicolumn{2}{|c|}{ Agree } & \multicolumn{2}{|c|}{ Neutral } & \multicolumn{2}{|c|}{ Disagree } \\
\hline & Frequency & Percentage & Frequency & Percentage & Frequency & Percentage \\
\hline 1 & 49 & $61.3 \%$ & 15 & $18.8 \%$ & 16 & $20 \%$ \\
\hline 2 & 44 & $55 \%$ & 25 & $31.3 \%$ & 11 & $13.7 \%$ \\
\hline 3 & 58 & $72 \%$ & 16 & $20 \%$ & 6 & $7.5 \%$ \\
\hline 4 & 23 & $28.7 \%$ & 20 & $25 \%$ & 37 & $46.3 \%$ \\
\hline
\end{tabular}

Appendix C. Frequencies \& Percentages of Attitudes towards the Culture \& Native Speakers of English $(\mathrm{N}=80)$

\begin{tabular}{|c|c|c|c|c|c|c|}
\hline \multirow{2}{*}{ Item } & \multicolumn{2}{|c|}{ Agree } & \multicolumn{2}{|c|}{ Neutral } & \multicolumn{2}{|c|}{ Disagree } \\
\hline & Frequency & Percentage & Frequency & Percentage & Frequency & Percentage \\
\hline 5 & 57 & $71.3 \%$ & 18 & $22.5 \%$ & . & $6.3 \%$ \\
\hline 6 & 50 & $62.5 \%$ & 20 & $25 \%$ & 10 & $12.5 \%$ \\
\hline 7 & 57 & $71.3 \%$ & 14 & $17.5 \%$ & 9 & $11.3 \%$ \\
\hline 8 & 71 & $88.8 \%$ & 8 & $10 \%$ & 1 & $1.2 \%$ \\
\hline
\end{tabular}

ApPendix D. Frequencies \& Percent ages of Attitudes towArds the IMPORTANCE OF ENGLISH IN THE PRESENT TIME $(\mathrm{N}=80)$

\begin{tabular}{|c|c|c|c|c|c|c|}
\hline \multirow[t]{2}{*}{ Item } & \multicolumn{2}{|c|}{ Agree } & \multicolumn{2}{|c|}{ Neutral } & \multicolumn{2}{|c|}{ Disagree } \\
\hline & Frequency & Percentage & Frequency & Percentage & Frequency & Percentage \\
\hline 9 & 70 & $87.5 \%$ & 9 & $11.3 \%$ & 1 & $1.2 \%$ \\
\hline 10 & 59 & $73.8 \%$ & 16 & $20 \%$ & 5 & $6.3 \%$ \\
\hline 11 & 66 & $82.5 \%$ & 9 & $11.3 \%$ & 5 & $6.3 \%$ \\
\hline 12 & 52 & $65 \%$ & 18 & $22.5 \%$ & 10 & $12.5 \%$ \\
\hline 13 & 59 & $73.8 \%$ & 9 & $11.3 \%$ & 12 & $15 \%$ \\
\hline
\end{tabular}

\section{ACKNOWLEDGMENTS}

This study was produced from the author's BA graduation project, which was conducted at the University of Bisha, Bisha, Saudi Arabia, during the second semester of the academic year 2020/2021, under the supervision of Dr. Ali Ayed Alshahrani.

\section{REFERENCES}

[1] Abu-Snoubar, T. (2017). An evaluation of EFL students' attitudes towards English language learning in terms of several variables, International Journal of English Language Teaching, 5(6), 18-34.

[2] Adnan, A. (2017). Learning English (and Arabic) in Malaysian Islamic schools: Language use and the construction of identities, Arab World English Journal, 8(3), 407-420. https://dx.doi.org/10.24093/awej/vol8no3.26

[3] Ajzan, I. (1988). Attitudes, Personality, and Behaviour. Chicago: Dorsey Press.

[4] Ali, J., Shamsan, M., Guduru, R., \& Yemmela, N. (2019). Attitudes of Saudi EFL learners towards speaking skills, Arab World English Journal, 10(2) 253-364. https://dx.doi.org/10.24093/awej/vol10no2.27

[5] Allport, G. (1935). Attitudes. In C. Murchison (Ed.), Handbook of Social Psychology (pp. 798-844). Worcester, MA: Clark University Press. 
[6] Al samadani, H., \& Ibnian, S. (2015). The relationship between Saudi EFL students' attitudes towards learning English and their academic achievement, International Journal of Education and Social Science, 2(1), 92-102.

[7] Alshamy, A. (2012). Attitudes and motivation of EFL learners towards English: A case study of PYP Saudi university students (MA Thesis). University of Sunderland, England.

[8] Al-Tamimi, A., \& Shuib, M. (2009). Motivation and attitudes towards learning English: A study of petroleum engineering undergraduates at Hadhramout University of Sciences and Technology, GEMA Online Journal of Language Studies, 9(2), 2955.

[9] Baker, C. (1992). Attitudes and Language. Clevedon, Multilingual Matters.

[10] Bhaskar, C., \& Soundiraraj, S. (2013). A study on change in the attitude of students towards English language learning, English Language Teaching, 6(5), 111-116. http://dx.doi.org/10.5539/elt.v6n5p111

[11] Ellis, R. (2004). Individual Differences in Second Language Learning. In A. Davies \& C. Elder (Eds.), The handbook of applied linguistics (pp. 525-547). Malden, Mass.: Blackwell.

[12] Gardner, R., \& Lambert, W. (1972). Attitudes and Motivation in Second Language Learning. Rowley, Mass.: Newbury House.

[13] Gardner, R. (1985). Social Psychology and Second Language Learning: The Role of Attitudes and Motivation. London: Edward Arnold.

[14] Iqbal, N., Aftab, H., \& Azhar, K. (2019). Attitudes of Islamic Learning and Education Faculty Students towards English language at Karachi University, Journal of English Teaching, 5(1), 38-49.

[15] Khan, I. (2016). Positive attitude and English language learning: Psycho-pedagogic connections, Arab World English Journal, 7(1), 432-444. https://dx.doi.org/10.24093/awej/vol7no1.26

[16] McKenzie, R. (2010). The Social Psychology of English as a Global Language: Attitudes, Awareness and Identity in the Japanese Context. Springer Dordrecht Heidelberg: London, New York. DOI: 10.1007/978-90-481-8566-5

[17] Orfan, N. (2020). Afghan undergraduate students' attitudes towards learning English, Cogent Arts \& Humanities, 7, 1-23. https://doi.org/10.1080/23311983.2020.1723831

[18] Wenden, A. (1991). Learner strategies for learner autonomy. New York: Prentice Hall.

[19] Yusoff, N. (2019). The Non-English Major Students' Perceptions towards the Use of English in Everyday Communication. Trends in Social Sciences, 1 (2), 15-24.

[20] Zeinivand, T., Azizifar, A., \& Gowhary, H. (2015). The Relationship between Attitude and Speaking Proficiency of Iranian EFL Learners: The Case of Darrehshehr City. Procedia - Social and Behavioral Sciences, 199, 240-247. DOI: 10.1016/j.sbspro.2015.07.512

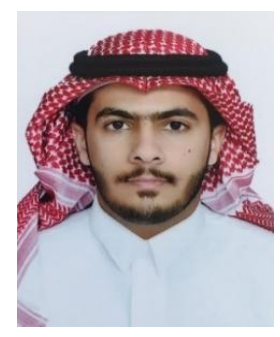

Nawaf J. Alsubaie was born in Saudi Arabia in 1999. He obtained a bachelor's degree in English language from the University of Bisha, Bisha, Saudi Arabia, in 2021. His research interests include, among other things, teaching and learning English as a foreign language. He produced this work from his BA graduation project, which was supervised by Dr. Ali Ayed Alshahrani, Associate Professor of applied linguistics at the said university.

ORCID: https://orcid.org/0000-0002-1676-4852 